\title{
Chromatometric comparison of Eurasian Collared Dove (Streptopelia decaocto) and Feral Pigeon (Columba livia domestica) feathers
}

\author{
Zoltán Bagi - János Posta - Szilvia Kusza \\ University of Debrecen Faculty of Agricultural and Food Sciences and Environmental Management, \\ Institute of Animal Sciences, Biotechnology and Nature Conservation, Debrecen, Hungary \\ bagiz@agr.unideb.hu
}

\begin{abstract}
SUMMARY
Chromatometric examination of the plumage of birds is a poorly researched topic. We have approached this issue in primarily aspect of differences in plumage of species. Moulted feathers sample collection method has been increasingly used. Reliable identification of feathers becomes an increasingly important issue, hence need for an exact measurement-based methodology. Eurasian Collared Dove (Streptopelia decaocto) and Feral Pigeon (Columba livia domestica) primary, secondary and tail feathers were studied. Chromatometric parameters of feathers were measured in CIELAB color system and then statistical analysis (Independent samples t-test, Descriptive Statistics, Discriminant Analysis) was performed to compare the two species. Instrumental measurements has been confirmed the high similarity between colors of the two species, however species specific differences were also found. Lightless ( $\left.L^{*}\right)$ value were significantly characteristic of particular species, while the red/green ( $\left.a^{*}\right)$ and yellow/blue $\left(b^{*}\right)$ value had lower Predictive Power. We identified feathers and the variables which useable to separate the two species and determined the associated Confidence Intervals of these values. Our results may draw attention to a new potential direction for exact identification of the moulted feathers during sample collection.
\end{abstract}

Keywords: CIELAB, Columbidae, color analysis, descriptive statistics, discriminant analysis, independent samples t-test, non-invasive sampling

\section{ÖSSZEFOGLALÁS}

A madarak tollazatának kromatometriai vizsgálata egy kevéssé kutatott téma jelenleg. Mivel a vedlett tollas mintagyüjtési módszert egyre szélesebb körben alkalmazzák, a tollak biztonságos, faji szintü azonositása egyre inkább elötérbe kerülö kérdés. Jelen tanulmányban a fajok tollazatának szinei közötti különbségekre koncentráltunk és egy egzakt méréseken alapuló fajazonositási módszert alakitottunk ki. Vadászaton elejtett balkáni gerlék (Streptopelia decaocto) és elvadult házi galambok (Columba livia domestica) elsödleges- és másodlagos evezötollait, valamint kormánytollait használtuk a vizsgálat során. A tollak kromatometriai paramétereit CIELAB szinrendszerben mértük, majd statisztikai elemzés (kétmintás t-teszt, leíró statisztika, diszkriminancia analizis) során hasonlitottuk össze a két fajt. A müszeres vizsgálatok is megerösitették a nagyfokú hasonlóságot a két faj között, de fajspecifikus különbségeket is sikerült kimutatnunk. Legtöbb esetben a világossági értékek ( $\left.L^{*}\right)$ jellemezték szignifikánsan a fajokat, míg a vörös-zöld ( $\left.a^{*}\right)$ és sárga-kék (b*) értékeknek kisebb volt a magyarázó ereje. Azonositottuk a két faj elkülönitésére használható tollakat és változókat, valamint az ezek értékeihez tartozó konfidencia intervallumokat. Eredményeinkkel szeretnénk felhivni a figyelmet a tollak azonosításának lehetséges új irányaira a vedlett tollas mintagyüjtés során.

Kulcsszavak: CIELAB, Columbidae, színvizsgálat, leiró statisztika, diszkriminancia analízis, független mintás t-próba, nem-invazív mintavétel

\section{INTRODUCTION}

In birds the chromatometric studies are using the most often skin, meat, egg and blood (McNeal et al., 2003; Ponte et al., 2004; Bianchi et al., 2006; Moreno et al., 2006; Doolan et al., 2007), the feathers are poorly used. Spectrometer instrument is used for these kind of studies. McGraw and Hill (2004) investigated the propensity for carotenoid-based color of feather patches in male house finches (Carpodacus mexicanus) to change during the breeding period. The value of hue change was a direct function of the amount of time between plumage scores; feathers faded more as the interval between measurements increased. They found that, the magnitude of hue did not change, however, related to an individual's age or initial plumage redness, which suggests that certain birds are not more or less prone to fading. These results imply that researchers should more carefully track plumage color expression during the course of a year, as seasonal color shifts may have important consequences for late season malemale competitive interactions and flexible female mating tactics (e.g. social mate switching, choice of extrapair partners). Toral et al. (2008) analysed measurements of carotenoids-based coloration components (lightness, chroma and hue) and lutein peak of the yellow breast of the great tit Parus major. The authors used two type of spectrometers (Ocean optics and Minolta) which calculate the color components differently. This study showed that direct measurement of bird was highly repeatable to determine lightness, chroma and hue for both spectrometers. Authors found similar results for collected feathers procedure for both devices. Collected feathers were provided high representative measurements of colour values with Minolta spectrometer. Lightness was highly repeatable when authors used Ocean optic spectrometer, but chroma and hue were moderated. Lutein peak was also highly repeatable in all cases. The number of feathers used to measure plumage coloration in collected feathers procedure can strongly influenced the values of colour plumage variables. In general, values of lightness, chroma and hue stabilised when more than 10-15 feathers were used although authors found slight differences between spectrometers. 
However, only four feathers were needed for lutein peak. Thus, this results stress the need to use a minimum number of feathers in measuring plumage coloration from collected feathers. Eliason and Shawkey's study (2010) describe dynamic color changes in all keratinous biophotonic nanostructure. This work shows that iridescent feather color varies rapidly and reversibly response to changes in ambient humidity. Based on optical models and sorption experiments, these changes appear to be caused by a swelling of the outer keratin cortex following water absorption. Based on these results we have strived to use same moisture content feathers in this study. Toral et al. (2008) investigated the differences in spectrum reflectance for six pigments resulting in red colorations in feathers of different species, with a focus on discriminating among melanins and carotenoids. They have also derived discriminant formulas for identification of the major known types of pigments based on parameters of the reflectance curves (UV and visible light) obtained with a portable spectrometer (Minolta CM-2600d). Equally used spectrometry and morphometric methods were used in the study of neck feathers of Mourning Dove (Zenaida macroura) in order to understand the background of dynamic changes of feather colors (Shawkey et al., 2011). Feathers are neither innervated nor vascularized and therefore any color change must be caused by external stimuli. It follows that the structure and physical condition of feathers have a significant impact to colors. Results suggested that some plumage colors may be more malleable than previously thought.

We studied the feather color of similar-looking species in aspect of species separation. This is justified by the increasing use of moulted feathers in scientific studies (Taberlet et al., 1999). This non-invasive sampling method has several advantages, such as relatively small quantity of feathers containing sufficient genomic DNA for further studies, due to the small quantity of the collection, storage, transport of samples is also easier and cheaper furthermore does not lead to the animal's death, damage or disturbance, and therefore does not pose a risk to the animal's health and fitness (Taberlet et al., 1999; McDonald and Griffith, 2011). However, these benefits can not prevail if we fail to unequivocally identify the feathers which are used as a sample. Practice shows that many years of research experience is not a guarantee, and in many cases there is a risk of misidentification. For that very reason, we need a method based on exact measurements. One possibility may be the chrometometric characterization and separation of species.

Eurasian Collared Dove (Streptopelia decaocto) and the Feral Pigeon (Columba livia domestica) have similar body size, feather colors and habitat use. The two species are equally prefer rural areas, where is significant agriculture, but there are also present in the urban parks and gardens (Coombs et al., 1981; Chamberlain et al., 2005). Our aim was to assess the possibility for separation of two similar color species by exact chromatometric method.

\section{MATERIAL AND METHODS}

Samples of dove (Streptopelia decaocto) and pigeon (Columba livia domestica) were collected from hunted or dead birds in two Hungarian towns: Elöszállás $(n=15)$ and Hajdúnánás $(n=9)$. The primarily and the secondary wing feathers as well as the tail feathers of all birds were stored at $-20^{\circ} \mathrm{C}$ for further study. For objective measurement of feather color, Minolta Chromameter CR-410 was used, what measures the reflectance of the light from feather compared to a calibration plate. The pulsed xenon arc lamp light source with baffle and diffuser allow light to travel only in the vertical direction to illuminate sample (Konica-Minolta, 2006). The meter was calibrated with a white plate. This tool is using an international color system standard. CIE L*a*b* (CIELAB) is the most complete color space specified by the Commission Internationale de l'Eclarige (CIE) (Sluzker et al., 2011). All the colors what is visible to the human eye is detected and its use serves as a device-independent model as a reference. The three coordinates of CIELAB represent the lightness of the color. The L* value shows the lightness of the color on a scale from 0 to 100 , the lower values indicating the darker color. The $a^{*}$ value indicates the red/green, while the $b^{*}$ value indicates the yellow/blue chromaticity of the color on a scale ranging from +60 to -60 (Tóth et al., 2006). These three colors attribute together to define the position of a specified color within a 3D color space (Radácsi et al., 2006). Due to the specific nature of the instrument feathers were measured in groups of five as seen they are placed on the wing as well. 1-1 measurements were carried out by both sides of the feather groups. In this study 17 dove and 7 pigeon individuals were used. The measurement was conducted by a single personnel.

During the statistical analyses, feather groups were marked as follows. Primary group 1 (PG1), primary group 2 (PG2), secondary group 1 (SG1), secondary group 2 (SG2), tail group (TG), verso (v). Independent samples t-test was used to detect differences between feather groups of two species based on three variables. The predictive power of the variables examined using discriminant analysis, and descriptive statistic was used for determinate the confidence intervals. IBM SPSS Statistics 21 (IBM Corp., 2012) software was used for all statistical evaluation.

\section{RESULTS AND DISCUSSION}

Independent samples t-test (Table 1) shows the differences between feather groups of two species based on three variables. It can be seen that in most cases there is no significant difference in values between the two species. The most significant differences were in the lightness values (L*). Discriminant analysis (Table 2) confirms this observation. Although the values were relatively high for all three variables, the lightness $\left(\mathrm{L}^{*}\right)$ predicted the greatest extent that belong to species. Predicted group membership (\%) column shows the model accuracy in the classification of feathers based on variables. 
Table 1. confidence intervals relating to variables and species

Level of significance between feather groups of two species based on independent sample t-test

\begin{tabular}{lccc}
\hline & $\mathrm{L}$ & $\mathrm{a}$ & $\mathrm{b}$ \\
\hline PG1 & $* * *$ & $* *$ & 0.117 \\
PG1v & $* * *$ & $*$ & $* *$ \\
PG2 & 0.054 & 0.610 & 0.224 \\
PG2v & $*$ & $* * *$ & $* *$ \\
SG1 & $* * *$ & 0.078 & 0.128 \\
SG1v & 0.551 & 0.982 & 0.379 \\
SG2 & 0.493 & 0.193 & 0.070 \\
SG2v & 0.544 & 0.126 & $* *$ \\
TG & $*$ & 0.493 & 0.078 \\
TGv & $* * *$ & $*$ & 0.156 \\
\hline
\end{tabular}

Note: $* \mathrm{p}<0.05, * * \mathrm{p}<0.01, * * * \mathrm{p}<0.001$

Table 2

Predictive power of variables based on discriminant analysis

\begin{tabular}{lcccc}
\hline & Variable & $\begin{array}{c}\text { Wilks' } \\
\text { lambda }\end{array}$ & $\begin{array}{c}\text { Predictive } \\
\text { power (\%) }\end{array}$ & \multicolumn{2}{c}{$\begin{array}{c}\text { Predicted group } \\
\text { membership (\%) }\end{array}$} \\
\cline { 4 - 5 } & & & Dove & Pigeon \\
\hline $\mathrm{L}$ & $0.014 * * *$ & 98.6 & 100 & 100 \\
$\mathrm{a}$ & $0.124 * * *$ & 87.6 & 100 & 100 \\
$\mathrm{~b}$ & $0.155^{* * *}$ & 84.5 & 100 & 100 \\
\hline & & &
\end{tabular}

Table 3 presents the confidence intervals of feather groups and variables combinations which showed significant differences between species (Table 1). These may be applied directly to species identification in the future.

Based on results we suggest to use the most informative variable, the lightless $\left(\mathrm{L}^{*}\right)$ for chromatometric feather separation and identification on species level. In case of doubt it is recommended involvement of additional two variables, the red/green $\left(a^{*}\right)$ and/or yellow/blue $\left(b^{*}\right)$. Thereby, the species which moulted the feather can be identified by on objective and exact way.

\section{CONCLUSIONS}

Our aim was to assess the possibility for separation of two similar color species by exact chromatometric method. We used two different species (Eurasian Collared Dove and Feral Pigeon) which feathers have very similar color and morphometric characteristics, and they share similar habitats. We confirmed the similarity between the two species colors by instrumental measurements, however separation possibility were also found. We demonstrated that the chromatometric methods are suitable for the separation of feathers at species level. In most cases, the lightless $\left(\mathrm{L}^{*}\right)$ value was significantly characteristic of particular species, while the red/green ( $\left.a^{*}\right)$ and yellow/blue $\left(b^{*}\right)$ values had lower predictive power. Combined use of the feathers in feathers group and variables with corresponding confidence intervals - which had appointed in this study - may be a fast and simple method to species identification.

Confidence intervals of feather groups and variables combinations which showed a significant difference

\begin{tabular}{|c|c|c|c|c|c|c|c|c|c|c|c|c|}
\hline & \multicolumn{12}{|c|}{$95 \%$ confidence interval of the difference } \\
\hline & \multicolumn{2}{|c|}{ Dove } & \multicolumn{2}{|c|}{ Pigeon } & \multicolumn{2}{|c|}{ Dove } & \multicolumn{2}{|c|}{ Pigeon } & \multicolumn{2}{|c|}{ Dove } & \multicolumn{2}{|c|}{ Pigeon } \\
\hline & Lower & Upper & Lower & Upper & Lower & Upper & Lower & Upper & Lower & Upper & Lower & Upper \\
\hline PG1 & 30.682 & 34.766 & 39.260 & 49.297 & 1.614 & 1.779 & 1.269 & 1.639 & n.d. & n.d. & n.d. & n.d. \\
\hline PG1v & 43.211 & 46.442 & 53.399 & 59.028 & 1.305 & 1.498 & 1.000 & 1.359 & 1.815 & 2.254 & 0.461 & 1.915 \\
\hline PG2v & 54.617 & 57.548 & 55.971 & 65.957 & 0.643 & 0.745 & 1.000 & 1.359 & -0.505 & -0.109 & 0.436 & 1.857 \\
\hline SG1 & 39.463 & 41.791 & 1.109 & 1.717 & n.d. & n.d. & n.d. & n.d. & n.d. & n.d. & n.d. & n.d. \\
\hline $\mathrm{SG} 2 \mathrm{v}$ & n.d. & n.d. & n.d. & n.d. & n.d. & n.d. & n.d. & n.d. & -0.455 & 0.069 & 0.326 & 1.747 \\
\hline TG & 34.169 & 36.149 & 29.956 & 35.049 & n.d. & n.d. & n.d. & n.d. & n.d. & n.d. & n.d. & n.d. \\
\hline $\mathrm{TGv}$ & 38.780 & 43.016 & 31.465 & 36.171 & 0.909 & 1.089 & 1.011 & 1.531 & n.d. & n.d. & n.d. & n.d. \\
\hline
\end{tabular}

Note: n.d.=no data, $\mathrm{p}<0.05$

In our opinion, this method, and a broader sense the chromatometric study of birds plumage involves a great potential and may verify additional research in this area. Further investigations are planned based on this methodology in Columbidae species, such as $\mathrm{Co}$ lumba palumbus, Streptopelia turtur, and Streptopelia risoria. Later, the study will be extended to other genera, such as Phasianidae, Anatidae, and Accipitridae. The main goal is to create a database that contains the appropriate variables and their values for identification.
We propose that this method can be applied in many other areas. For example, it may be useful for separating protected and huntable species pairs in judicial procedures or for species that cause economic damage. For example, the application of the method has been suggested for the identification of Cormorant subspecies (Phalacrocorax carbo carbo and Phalacrocorax carbo sinensis) on fish farms. Our developed method could be useful for detecting rare species in their habitat because it is left only indirect evidence behind (moulted feathers). 


\section{REFERENCES}

Bianchi, M.-Petracci, M.-Cavani, C. (2006): The influence of genotype, market live weight, transportation, and holding conditions prior to slaughter on broiler breast meat color. Poultry Science. 85. 1: 123-128.

Chamberlain, D. E.-Vickery, J. A.-Glue, D. E.-Robinson, R. A.Conway, G. J.-Woodburn, R. J.-Cannon, A. R. (2005): Annual and seasonal trends in the use of garden feeders by birds in winter. Ibis. 147. 3: 563-575.

CIE (2015): Commission internationale de l'éclairage. (accessed 11 February 2015) (http://www.cie.co.at)

Coombs, C. F. B.-Isaacson, A. J.-Murton, R. K.-Thearle, R. J. P.Westwood, N. J. (1981): Collared doves (Streptopelia decaocto) in urban habitats. Journal of Applied Ecology. 18: 41-62.

Doolan, B. J.-Booth, M. A.-Jones, P. L.-Allan, G. L. (2007): Effect of cage colour and light environment on the skin colour of Australian snapper Pagrus auratus (Bloch \& Schneider, 1801). Aquaculture Research. 38. 13: 1395-1403.

Eliason, C. M.-Shawkey, M. D. (2010): Rapid, reversible response of iridescent feather color to ambient humidity. Optics Express. 18. 20: 21284-21292.

Konica-Minolta (2006): Konica Minolta Chroma Meter Cr-200/ CR-210, CR-221/CR-231. 3 ed. Osaka, Japan: Konica Minolta Sensing Inc.

McDonald, P. G.-Griffith, S. C. (2011): To pluck or not to pluck: the hidden ethical and scientific costs of relying on feathers as a primary source of DNA. Journal of Avian Biology. 42. 3: 197-203.

McGraw, K. J.-Hill, G. E. (2004): Plumage color as a dynamic trait: carotenoid pigmentation of male house finches (Carpodacus mexicanus) fades during the breeding season. Canadian Journal of Zoology. 82. 5: 734-738.

McNeal, W. D.-Fletcher, D. L.-Buhr, R. J. (2003): Effects of stunning and decapitation on broiler activity during bleeding, blood loss, carcass, and breast meat quality. Poultry Science. 82. 1: 163-168.
Moreno, J.-Lobato, E.-Morales, J.-Merino, S.-Tomás, G.Martínez-de la Puente, J.-Sanz, J. J.-Mateo, R.-Soler, J. J. (2006): Experimental evidence that egg color indicates female condition at laying in a songbird. Behavioral Ecology. 17. 4: 651-655.

Ponte, P. I. P.-Ferreira, L. M. A.-Soares, M. A. C.-Aguiar, M. A. N. M.-Lemos, J. P. C.-Mendes, I.-Fontes, C. M. G. A. (2004): Use of cellulases and xylanases to supplement diets containing alfalfa for broiler chicks: effects on bird performance and skin color. The Journal of Applied Poultry Research. 13. 3: 412-420.

Radácsi, A.-Béri, B.-Bodó, I. (2006): Objective measurement of coat color varieties in the hungarian grey cattle. Proceedings of the $57^{\text {th }}$ Annual Meeting of the European Association for Animal Production. Antalya. Turkey. 307.

Shawkey, M. D.-D’Alba, L.-Wozny, J.-Eliason, C.-Koop, J. A.-Jia, L. (2011): Structural color change following hydration and dehydration of iridescent mourning dove (Zenaida macroura) feathers. Zoology. 114. 2: 59-68.

Sluzker, A.-Knösel, M.-Athanasiou, A. E. (2011): Sensitivity of digital dental photo CIE L* a* b* analysis compared to spectrophotometer clinical assessments over 6 months. American Journal of Dentistry. 24. 5: 300 .

Taberlet, P.-Waits, L. P.-Luikart, G. (1999): Noninvasive genetic sampling: look before you leap. Trends in Ecology \& Evolution. 14. 8: 323-327.

Toral, G. M.-Figuerola, J.-Negro, J. J. (2008): Multiple ways to become red: pigment identification in red feathers using spectrometry. Comparative Biochemistry and Physiology Part B: Biochemistry and Molecular Biology. 150. 2: 147-152.

Tóth, Z.-Kaps, M.-Soelkner, J.-Bodo, I.-Curik, I. (2006): Quantitative genetic aspects of coat color in horses. Journal of Animal Science. 84. 10: 2623-2628. 